\title{
The empirical research on Social Media-oriented Interactive Marketing Strategy based on Suning.com
}

\author{
He Siyu \\ School of Economics and Management \\ University of Science and Technology Beijing \\ Beijing, China \\ hsy_1993@sina.com
}

\begin{abstract}
The paper has made analysis on marketing environment such as micro-blog, companies and market, as well as advantages and disadvantages of Suning.com with questionnaires. The author puts forward his online marketing strategy with micro-blog -- a social media-oriented interactive marketing means and offers a specific marketing program. The budget analysis is also made on cost-related factors affecting a micro-blog marketing team, including manpower, time and financial resources, etc..
\end{abstract}

Keywords- Marketing Strategy; Micro-blog; E-commerce; Suning.com

I.

INTRODUCTION

Informally, marketing is something that you sell what you want to sell, serve well your targeted customer, raise your customer's loyalty, cultivate your targeted customer group and establish your customer channel.

Based on the social media-oriented interactive platform, Suning.com aims at fully understanding the current customers through background analysis and survey on market, making it possible that products and services of Suning are perfectly up to the needs of customers and products would then be sold out by themselves. At the same time, potential customers should be cultivated and developed with better services. The marketing objective is to put forward comparatively reasonable marketing measures suitable for the public through market survey and analysis, making a better promotion of Suning products on the market.

\section{FEASIBILITY ANALYSIS OF SUNING.COM SOCIAL MEDIA-ORIENTED INTERACTIVE MARKETING}

With the rapid development of modern network technology and marketing methods, a high-tech e-business war without gun smoke is waged between online virtual businesses and traditional retail business. Marketing strategy and methods become both the magic and fatal weapon.

Suning takes Suning.com as a touchstone in the field of e-business in 2010. The sales volume of Suning.com already reached RMB2B in less than one year and soared to RMB5.9B in 2011. In contrast, Dangdang.com has got involved in e-business for 10 years and its sales volume was only up to RMB $2.3 \mathrm{~B}$ in 2010 . The big success stimulated Suning to accelerate its distribution of e-businesses and invest on Suning.com with more money since then. The marketing strategy of Suning becomes clear gradually. Suning established the coordinated development framework for three strategic business units, which are respectively 'Suning Chains, Laox Chains and Suning.com', taking shape its online and offline interactive business development model and focusing on promoting transition of business model and optimized profit model. The continuously expansion of Suning.com will become the key of Suning's transformation in the next step.

Micro-blog is a broadcast social networking platform through the mechanism of concern and sharing short realtime information. It becomes the most popular social network gradually and more and more companies have come to understand its importance. Micro-blog becomes the representative of the growing emerging network products and new e-business model day by day.

Suning.com, a new member of online shops, should take micro-blog as its major core of promotion. It is well known that micro-blog is the access to users on the market.

\section{A. Survey and analysis on feasibility of micro-blog marketing}

We focused our survey and analysis on the use of microblog among college students, including their understanding of micro-blog marketing and their online shopping experiences. With the results of survey, we analyzed and summarized the advantages and disadvantages of micro-blog marketing

INFORMATION CUSTOMERS WANT TO READ ON THE MICROBLOG OF AN ENTERPRISE

\begin{tabular}{|c|c|c|c|}
\hline $\begin{array}{c}\text { Another channel to } \\
\text { get to know } \\
\begin{array}{c}\text { information about } \\
\text { the product } \\
\text { in more details }\end{array}\end{array}$ & $\begin{array}{c}\text { Interactive } \\
\text { communication, get to } \\
\text { know more information } \\
\text { about experiences } \\
\text { of using the product }\end{array}$ & $\begin{array}{c}\text { A share } \\
\text { of } \\
\text { feelings }\end{array}$ & $\begin{array}{c}\text { Do not } \\
\text { care }\end{array}$ \\
\hline $70.56 \%$ & $37.23 \%$ & $29.44 \%$ & $13.87 \%$ \\
\hline
\end{tabular}

II.

TABLE 2. REASONS CUSTOMERS FOCUS ON THE MICROBLOG OF AN ENTERPRISE 


\begin{tabular}{|c|c|c|c|c|c|}
\hline $\begin{array}{c}\text { Activi } \\
\text { ty of } \\
\text { micro } \\
\text {-blog, } \\
\text { includ } \\
\text { ing } \\
\text { focus } \\
\text { es, } \\
\text { comm } \\
\text { ents } \\
\text { and } \\
\text { forwa } \\
\text { rds, } \\
\text { etc. }\end{array}$ & $\begin{array}{l}\text { Dive } \\
\text { rsifie } \\
\mathrm{d} \text { and } \\
\text { high } \\
\text { quali } \\
\text { ty } \\
\text { prod } \\
\text { ucts } \\
\text { or } \\
\text { servi } \\
\text { ce }\end{array}$ & $\begin{array}{c}\text { Post of } \\
\text { informati } \\
\text { on, such } \\
\text { as } \\
\text { various } \\
\text { marketin } \\
g \\
\text { activities, } \\
\text { lucky } \\
\text { draw and } \\
\text { special } \\
\text { offer }\end{array}$ & $\begin{array}{c}\text { Bran } \\
\mathrm{d}\end{array}$ & $\begin{array}{c}\text { Initiat } \\
\text { ive } \\
\text { and } \\
\text { intera } \\
\text { ctivit } \\
\text { y of } \\
\text { micro } \\
\text { blogg } \\
\text { er }\end{array}$ & $\begin{array}{l}\text { Attracti } \\
\text { on of } \\
\text { micro- } \\
\text { blog } \\
\text { content } \\
\text { and } \\
\text { interfac } \\
\text { e }\end{array}$ \\
\hline $43.55 \%$ & $46.23 \%$ & $35.28 \%$ & $\begin{array}{c}49.88 \\
\%\end{array}$ & $21.9 \%$ & $29.93 \%$ \\
\hline
\end{tabular}

Through survey investigation and analysis, we come to understand expectations of customers to the micro-blog of an enterprise. Most of customers want to get full and complete information of products from different channels. Suning can both introduce itself and promote its products on micro-blog.

The survey has proved that $15.33 \%$ of the micro-blog users would share the information and invite theirs friends to take concern over the product they do not buy. $62.04 \%$ of the users would choose to share the product they are interested in. $28.56 \%$ of the users would take concern over the product they bought and share the information. $56.2 \%$ of the users would do as the case may be. $14.29 \%$ of the users would speak highly of their satisfied online shopping. $22.23 \%$ of the users would express their dissatisfaction. $37.20 \%$ of the users would make comments on each online shopping they experienced. $36.25 \%$ of the users would prefer to share their good experience. $18.98 \%$ of the users would share their unpleasant experience and the rest users would share all they experienced. After reading all these comments on experiences, $10.71 \%$ of the users would be prone to believing the positive information and $25.06 \%$ of the users would be more prone to believing the negative information which will bring about big impact on their future online shopping activity. More micro-blog users, accounting for $64.23 \%$, would make rational analysis and verify the accuracy of the information.

III.

TABLE3. RECOGNITION OF ONLINE SHOPS

\begin{tabular}{|c|c|c|c|c|c|}
\hline Taobao.com & Suning.com & Paipai.com & JD.com & Gomecom.cn & Others \\
\hline $91.62 \%$ & $42.71 \%$ & $30.54 \%$ & $73.25 \%$ & $11.78 \%$ & $2.79 \%$ \\
\hline
\end{tabular}

Recognition of interviewers to different online shops is shown in Table 3. We can see that recognition of Suning.com is much lower than that of JD.com. $53.92 \%$ of the users give up to shop on Suning.com because they are not familiar with it and worry about its safety. Therefore, the top priority of Suning.com is to improve the recognition of its platform.

Micro-blog users are composed of a wide range of groups. Micro-blog marketing is being accepted and widely used day by day. Micro-bloggers are always active in the virtual world. They post their conditions, share information of others, get involved in and influence the marketing and development of enterprises. Enterprises should take full advantage of the micro-blog marketing model and increase its market share with a stronger brand.

\section{B. Advantages of micro-blog marketing}

The traditional marketing model which used to be that sellers led the market and customers accepted the products passively, has disappeared forever. The awareness of customers to actively search, understand and choose products as well as share shopping experiences is growing stronger. As a new e-business model, Micro-blog marketing has been gradually accepted by the public.

With the open-type group chat model, Micro-blog has attracted more and more audiences. From the huge number of potential audiences, Micro-blog marketers could figure them out and turn them into actual customers and a stable customer base could be established therefrom.

There are existing corporate customers or partners among micro-blog audiences. Micro-blog, as a channel of communication, could help maintain long-term and stable relationship with these customers and business partners. Likewise, Micro-blog could also help increase their loyalty.

Sufficient information could be found in micro-blog, including industry events, latest statistical data, competitors' events and products information.

With its real-time communication and interactive function, Micro-blog could help enterprises understand the comments of customers on their products and service and their need as well. A good comment would be forwarded like snowballing and a bad one would be focused and disseminated. Micro-blog could help enterprises find out solutions for the problems existed. Enterprises could improve themselves, respond the market quickly and upgrade corporate images accordingly. In the meanwhile, Micro-blog could reduce the cost of communications with customers and provide more convenience to customers.

Micro-blog could help enterprises promote themselves to a bigger extent, such as brand culture, business philosophy, products \& services and special offers. Micro-blog could help enterprises pool the wisdom of the masses and provide personalized services to customers with creative and different marketing plans.

\section{ANALYSIS ON CURRENT SITUATION OF SUNING.COM}

Network marketing needs to change the traditional marketing strategy. An enterprise must position itself according to the design, development, packing and brand of the products in conjunction with features of network and developed technologies.

What makes Suning.com different from other online shops is the important relationship between Suning.com and Suning Appliance, as they have a stake in each other's success. The Six People Law could bring about huge effects to each order of e-business. Compared with other online shops such as JD.com and Amazon.cn, the unique of Suning.com just enlarges the effects to a much bigger extent. Every order from the retail store can produce influence not only upon the creditability of online shops of Suning.com, but also upon comments of customers. Suning retail stores could be as well affected to a certain degree. To Suning, the importance of Suning.com could be seen easily. 


\section{A. Existing disadvantages}

- $\quad$ Limited cognitive communities and monopolized market

Although online shops are emerging on a roll nowadays, customers usually purchase goods on the shops with fames only, which are respectively JD.com, Taobao.com and
Dangdang.com. These few online shops are just sharing the whole online market. Results of a survey in Table 4 indicate that the majority of online purchasers choose Taobao.com to place their orders. Under such circumstances, it is surely very difficult for new online shops to take a share on the market.

IV.

FROM WHAT ONLINE SHOPS DO YOU USUALLY PURCHASE OVER THE LAST YEAR

\begin{tabular}{|c|c|c|c|c|c|c|c|c|c|}
\hline Taobao.com & Dangdangc.om & Amazon.cn & DJ.com & M18.com & Paipai.com & Vancl.com & Newegg.com & Eachnet.com & Others \\
\hline $99.1 \%$ & $34.8 \%$ & $24.1 \%$ & $11.2 \%$ & $6.7 \%$ & $5.4 \%$ & $4.0 \%$ & $3.6 \%$ & $3.1 \%$ \\
\hline
\end{tabular}

The brand Suning Appliance has been rooted in people's mind so deeply that whenever Suning is mentioned, their first reaction would be its retail store. Few people would know or come to think of the online Suning.com. Even if Suning.com is listed on top of links Baidu recommended, few people would search for Suning.com online. If only a few people know about Suning.com, then access to the market would be limited. To an online shop, this is the biggest issue. Suning.com will have face great difficulty to promotion itself and improve its recognition.

- Weak service capability and safety

The attitude of service and quality of service are commonly accepted as the truth of marketing as they decide customers' choice. The speed, quality and attitude of reply from the customer service affect not only the mood of consumers, but also the sales of commodities directly.

With a rather improved logistic and management system, Suning.com can directly deliver the goods from its retailer's storehouse that can shorten delivery time, but the accurate time of planned delivery can't be ensured. Delayed delivery or inaccurate time of delivery might influence the follow-up orders.

Network safety and lack regulation of enterprises would result in ineffective protection of customers' privacy. At present, information of customers are being used in chaos that personal information are commonly used in marketing activities. Without rational and legal management strategies, customers would be lost finally.

Position of prices fixed for goods sold online are also important factors. Only rational prices can maintain the Consumers.

\section{B. Existing advantages}

- Guaranteed brand

Compared with other online shops like JD.com and Taobao.com, the brand of Suning retail shops has clear big advantage. New Taobao shops need to cultivate their reputation and good comments at the early stage and manage to attract more customers. Suning can just save the timeconsuming stage. As a big brand, customers would shift the reputation, quality and service of Suning retail shops directly to Suning.com, which will surely shorten the time Suning.com need to grow itself and increase its competitiveness.

- Convenient goods management
To each online shop, the top issue is to determine where to store the goods in early days of its operation, which needs huge amount of manpower, materials, time and money. If the shop decides to cooperate with couriers, the speed of delivery would be a big concern. Suning.com has no such worries. Reorganized storehouses of Suning retail shops would be able to meet the needs of Suning.com. In addition, retail shops on the mainland are so extensively established that immediate and timely delivery could be achieved with the pattern of a region with a delivery spot or even a region with several storehouses.

- Guaranty with fund and manpower

Suning Appliance tops 59 among Top 500 Chinese Enterprises, tops 1 among Top 500 Chinese Privately-run Enterprises and has been listed in Top 100 Chinese Brands with Best Reputation. The value of Brand Suning has been up to RMB35.177B. With strong backing of manpower and materials, Suning.com is capable of accomplishing many large scale commercial strategies.

\section{SUNING.COM SOCIAL MEDIA-ORIENTED INTERACTIVE MARKETING STRATEGY}

\section{A. Team building}

As a large enterprise, Suning.com can build its marketing team with the honey-comb frame model (Figure 1) and the clearly divided responsibility system. The director, the person-in-charge, the editor and the operator should perform well their due roles, who are respectively responsible for the planning, editing, issuing, maintaining and monitoring of the micro-blog of Suning.com.

$\begin{aligned} & \rightarrow \text { Market } \rightarrow \text { Group A } \\ \text { Micro-blog } & \rightarrow \text { Customer service } \rightarrow \text { Group B } \\ & \rightarrow \text { Planning } \rightarrow \text { Group C }\end{aligned}$

1.

Team building

\section{B. Micro-blog marketing}

Each large website has its official micro-blog, such as sina.com, people.com.cn, sohu.com, 163.com, qq.com, and ifeng.com. Many SNS communities, BBS, vertical communities and comprehensive websites have issued their micro-blogs as well. Since a micro-blog can't cover all 
micro-blogger groups, Suning.com has settled itself on Sina.com and qq.com. Suning.com should get its micro-blog registered on some other websites. In the meanwhile, same contents should be issued timely in micro-blogs on different websites.

Suning.com should motivate its employees to join the micro-blog marketing team. With an individual micro-blog, each employee of Suning.com could focus, share and comment with each other. In such circumstances, micro-blog is more like a staff community that consumers can see the state of each employee of Suning.com when they skim through the micro-blog. Consumers may take Suning.com as their old friend and feel like themselves a member of the company. With such ideas in their mind, customers would prefer to choosing those shops they are familiar with.

The importance of micro-blog marketing should be people-oriented. Contents in the micro-blog should be attractive and interesting, drawing near the distance from customers. For instance, the micro-blog can include briefings of Suning Appliance, forward of hot news with unique comments, online shopping anecdotes, recommended products, interesting questions and answers, exchanges among customers, etc. It will do when customers couldn't help expect something might happen in the micro-blog.

There must be a special column in the micro-blog for communications between customers and Suning.com in order to solve problems of customers quickly. The microblog should also cooperate with other marketing channels, online/offline channels and offline commercial activities.

\section{Expanding publicity}

Since online shops takes young netizens as targeted consuming groups, online publicity is surely of the utmost importance. What can be done is to take and post online videos, set up micro-blog, main page and company blogs, etc. Exchanges of links with other websites can also be done to improve quality of the blog contents and concern of consumers.

It is a wise choice to set up the tie between customers and company via micro-blog. An enterprise can take a short message, a simple vote and a call for plan on micro-blog as important propaganda and marketing measures.

The extensively spread micro-blog could help customers understand products, services as well as the value $\&$ concept of the company better. If customers become preachers of an enterprise, namely interpersonal channel, the most favored way of advertisement is achieved therefore.

Coupons could be offered to newly registered members or micro-blog followers of enterprises through promoting activities on micro-blog. The most popular consumer award and the most faithful consumer award could be issued regularly or irregularly by offering vouchers as bonus.

Recognition of Suning.com should be improved in some other channels. Traditional media channels like radio, TV, newspaper, magazine and leaflets can also be used to increase the popularity of Suning.com. Suning.com should manage to include audiences and readers of these media into its targeted consumer groups.

\section{Improving service quality}

Providing perfect service plays an important role in the development of Suning.com. Backed by its retail shops, after-sales service of Suning.com can be unified with Suning retail shops. Thus, troubles of Suning .com can be reduced and rights of customers can be ensured.

Credits activity and membership system can be developed. Incentives can be worked out to keep faithful customers away from promotions of competitors. Therefore, costs of enterprises can be deduced and customer groups can be maintained with a better image.

Privacy of customers must be further protected. Customers should be guaranteed with the right to know, the right to choose, the right of access and safety of personal information.

The speed and quality of logistics should be improved. With clear delivery time and online search for logistic information, customers can know what is going on with their goods purchased at any time.

\section{E. High quality and low price strategy}

Online shops must have the power to impress customers. Commodities that could attract more and more customers must be in a full range of variety, in novel style and suitable for consumers from different circles of life. Based on such conditions, prices of goods must be cheap. Buying goods at lower price with higher quality would make customers feel assured and contented that they get for what they paid for. Customers would think online shops are too greedy if prices are fixed very high. In such circumstance, multiple commodities would become nothing but a picture or a furnishing in online shops that many consumers would just get away. However, prices of goods couldn't be too low. Many online shops are fighting fiercely with price competition in order to attract customers. As a matter of fact, price war is not advisable, as it can support only for a while but not for long.

We interviewed 100 students at random in campus for their options of price and quality. Please see Table 5 for details.

V.

OPTIONS OF PRICE AND QUALITY

\begin{tabular}{|c|c|c|c|c|}
\hline & $\begin{array}{c}\text { High } \\
\text { price and } \\
\text { high } \\
\text { quality }\end{array}$ & $\begin{array}{c}\text { Normal } \\
\text { price and } \\
\text { high } \\
\text { quality }\end{array}$ & $\begin{array}{c}\text { Low price } \\
\text { and } \\
\text { fine } \\
\text { quality }\end{array}$ & $\begin{array}{c}\text { Extremely low } \\
\text { price } \\
\text { and unknown } \\
\text { quality }\end{array}$ \\
\hline $\begin{array}{c}\text { No. of } \\
\text { persons }\end{array}$ & 8 & 32 & 54 & 6 \\
\hline
\end{tabular}

\section{F. Marketing channels}

- Structure of channels centering on end-use market building

Since the market is relatively saturated nowadays, the business model of enterprises couldn't focus only on maintaining and managing marketing channels, building and maintaining end-use market should be strengthened as well. To attract more customers, end-use market should be targeted to meet the needs of consumers.

- Channels of partnership membership should be developed

Integrated business should be done among companies, manufacturers and retail outlets. Companies should set the same goals with manufacturers and scattered retail outlets 
should be reorganized into an organic system. Members of channels should make common efforts to achieve their individual goals or objectives of all.

- Flattened channel system should be developed

Flattened structure of marketing channels indicates that links of marketing channels are getting shorter and the number of retail outlets is growing. The shortened marketing links can strengthen the power of control over the channels and the increased outlets can effectively promote the sales volume of products. Additionally, benefits of suppliers can be ensured since a partnership of stable cooperation has been set up with each other. Direct trading in a short-term could reduce the relevant cost and expand the scale of benefits.

\section{G. Budget of cost}

- Manpower cost of micro-blog marketing team

It is really necessary to set up a team for micro-blog marketing. The team must be composed of those with sufficient capability and high quality. They are usually professionals with strong capacity, who knows well about the business and understand management, market, psychology, technology, communication and coordination. These professionals are paid generally with comparatively high salary. An ordinary micro-blog operator would usually get a salary which is $50 \%$ higher than that of a staff working on other post in an enterprise.

- Time cost of micro-blog marketing team

Since quite many people use micro-blog between 08:00 to $24: 00$, the micro-blog marketing team needs to practice real-time monitoring and interaction with customers. Besides, they need to post important notices or urgent information timely. All these facts show that the regular working hour system couldn't work, which means time cost of the micro-blog marketing team could be much higher than that of an ordinary staff member.
- Financial cost of micro-blog marketing team

Various activities of micro-blog marketing can be carried out, such as promotions and special offers. Financial investment on these activities is for sure necessary. If the enterprise outsources its micro-blog marketing and management, financial investment will have to make on paying the service by corresponding agreement. Faced with breaking event or crisis, the enterprise needs to put in additional manpower, materials, financial resources and time to practice effective and timely crisis management on microblog.

\section{ACKNOWLEDGMENT}

$\mathrm{T}$ the authors sincerely appreciate all experts for their date and advice.

\section{REFERENCES}

1. Y Qian, Y F Bu, "Analysis on Micro-blog Marketing Model Based on Influence Study", Inquiry into Economic Issues, 2011 (12),pp. 117-121.

2. L Huang, "Study on Advantages and Strategies of Enterprises to Practise Micro-blog Marketing", Jiangsu Commercial Forum, 2012,26(05),pp,95-96+100.

3. Z Li, "Situation and Development Strategy of Micro-blog Marketing", China Economic \& Trade Herald2011 (16),pp.66-67.

4. L F Su, W M Shen, "How Far Can Suning.com Go? -Can the Most Powerful Traditional Retailers Be a Good E-Business?",2011 (11),pp. 30-38.

5. W G Jin, J Hu, Y B Li, "Analysis on Growth and Future of the New E-Business Suning.com",Microcomputer and its Applications, 2011,30(17),pp.1-3.

6. Nan Z, 'A Survey on College Students' Contact and Use Behavior of Micro-blogging Marketing “. East China Normal University,2011 